\title{
Synthesis, Properties and Environmentally Important Nanostructured and Antimicrobial Supramolecular Coordination Polymers Containing 5-(3-Pyridyl)-1,3,4-Oxadiazole-2-Thiol and Benzimidazole
}

\author{
Aref AM Aly*, Mahmoud A Ghandour, Bahaa M Abu-Zied and Maged S Al-Fakeh
}

Department of Chemistry, Faculty of Science, Assiut University, Assiut Egypt

\begin{abstract}
A new series of coordination polymers of $\mathrm{Co}(\mathrm{II}), \mathrm{Ni}(\mathrm{II}), \mathrm{Cu}(\mathrm{II}), \mathrm{Cd}(\mathrm{II})$ and $\mathrm{UO}_{2}(\mathrm{II}), 5$-(3-pyridyl)-1,3,4-oxadiazole2-thiol (POZT) and benzimidazole (BIMZ) has been prepared and characterized. The compounds have been characterized based on elemental analysis, FT-IR and electronic spectral studies, thermal analysis and X-ray powder diffraction. Thermogravimetry (TG), derivative thermogravimetry (DTG) and differential thermal analysis (DTA) have been used to study the thermal decomposition steps and to calculate the thermodynamic parameters of the nanosized metal coordination polymers. The kinetic parameters have been calculated making use of the Coats-Redfern and Horowitz-Metzger equations. The scanning electron microscope SEM photographs and particle size calculations from the powder XRD data indicate the nano-sized nature of the prepared supramolecular coordination polymers (average size 17-28 nm). The antimicrobial activity of the synthesized compounds was tested against six fungal and five bacterial strains. The majority of compounds were effective against the tested microbs. The bacteria and fungi strains are common contaminants of the environment in Egypt. In this article the studied strains are frequently reported from contaminated soil, water and food.
\end{abstract}

Keywords: Coordination polymers; X-ray powder diffraction, Thermal studies and biological activity.

\section{Introduction}

In recent decades, metal-organic frameworks (MOFs) are extensively developed as a new type of functional crystalline materials for a wide range of promising applications in separation, storage, exchange, and heterogeneous catalysis due to their high stability and structural diversity [1-4]. In general, the final coordination polymers significantly depend on the metal and ligand precursors [5]. Recently, a variety of pyridyl connectors have been extensively applied in this facet [6]. It should be noted that organosulfur compounds, which play an important role in chemical or biological processes are well documented [7]. Heterocyclic thiones are known in the field of coordination chemistry because of their potential multifunctional donor sites, viz either exocyclic sulfur or endocyclic nitrogen [8]. The pyridyl oxadiazoles are suitable bridging ligands for the synthesis of coordination polymers and several papers were published on using cyclized pyridyl 1,3,4-oxadiazoles for the preparation of metal complexes [9-11]. By changing the steric and electronic properties of ancillary organic ligands such as the heterocycle $\mathrm{N}$-donor molecules, (e.g. benzimidazole), it was possible to modulate the construction and the dimension of the polymeric coordination network [12]. Also benzimidazole belongs to a class of compounds which are of interest because of their pharmaceutical, analytical, most common binding sites in various metalloenzymes and industrial applications [13]. The chemistry of uranium is the most developed, due to the low radioactivity of one of its isotopes and its wide use at industrial and laboratory scales [14]. Uranium (VI) tends to form linear cation with two oxygen atoms $\mathrm{UO}_{2}{ }^{2+}$ which can be further surrounded by a number of anions commonly lying in one plane, which is perpendicular to $\mathrm{O}-\mathrm{U}-\mathrm{O}$ structure [15]. In this work, we synthesized and characterized new coordination polymers derived from the bridging ligand 5-(3-pyridyl)1,3,4-oxadiazole-2-thiol, benzimidazole and $\mathrm{Co}(\mathrm{II}), \mathrm{Ni}(\mathrm{II}), \mathrm{Cu}(\mathrm{II})$, $\mathrm{Cd}(\mathrm{II})$ and $\mathrm{UO}_{2}(\mathrm{II})$.

\section{Material and Methods}

High purity 5-(3-pyridyl)-1,3,4-oxadiazole-2-thiole and benzimidazole were supplied from Sigma Aldrich and Merck. All other chemicals were of AR grade. Figure 1 shows the structure of the ligands.

\section{Physical measurements}

Elemental analysis (carbon, hydrogen, nitrogen and sulphur) were

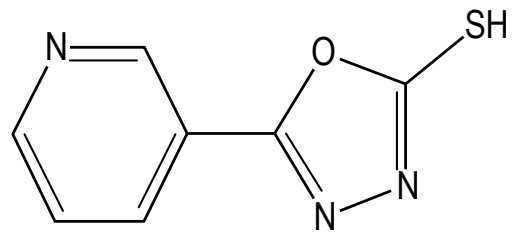

5(3-pyridyl)-1,3,4-oxadiazole-2-thiol POZT

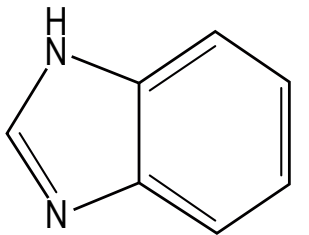

Benzimidazole BIMZ
Figure 1: Chemical structure of POZT and BIMZ.

*Corresponding author: Aref A.M.Aly, Department of Chemistry, Faculty of Science Assiut University, Assiut Egypt, Tel: +201003486619; Fax: 0020-88-2342708; E-mail: aref_20002001@yahoo.com

Received February 03, 2012; Accepted February 24, 2012; Published February 26, 2012

Citation: Aly AAM, Ghandour MA, Abu-Zied BM, Al-Fakeh MS (2012) Synthesis Properties and Environmentally Important Nanostructured and Antimicrobial Supramolecular Coordination Polymers Containing 5-(3-Pyridyl)-1,3,4Oxadiazole-2-Thiol and Benzimidazole. J Environment Analytic Toxicol 2:129. doi:10.4172/2161-0525.1000129

Copyright: ( 2012 Aly AAM, et al. This is an open-access article distributed unde the terms of the Creative Commons Attribution License, which permits unrestricted use, distribution, and reproduction in any medium, provided the original author and source are credited. 
Citation: Aly AAM, Ghandour MA, Abu-Zied BM, Al-Fakeh MS (2012) Synthesis, Properties and Environmentally Important Nanostructured and Antimicrobial Supramolecular Coordination Polymers Containing 5-(3-Pyridyl)-1,3,4-Oxadiazole-2-Thiol and Benzimidazole. J Environment Analytic Toxicol 2:129. doi:10.4172/2161-0525.1000129

Page 2 of 7

performed using Analyischer Funktionstest Vario El Fab-Nr.11982027 elemental analyzer. Infrared spectra were recorded as $\mathrm{KBr}$ disks (400-4000 $\mathrm{cm}^{-1}$ ) with a FT-IR spectrophotometer model (ThermoNicolet-6700 FTIR) and the electronic spectra were obtained using a Shimadzu UV-2101 PC spectrophotometer. Magnetic susceptibility measurements were done on a magnetic susceptibility balance of the type MSB-Auto. The conductance was measured using a conductivity Meter model 4310 JENWAY. Thermal studies were carried out in dynamic air on a Shimadzu DTG $60-\mathrm{H}$ thermal analyzer at a heating rate $10^{\circ} \mathrm{C} \mathrm{min}{ }^{-1}$. XRD Model PW 1710 control unit Philips, Anode material Cu 40 K.V 30 M.A Optics: Automatic divergence slit. Scanning electron microscope (JEOL JFC-1100E ION SPUTTERING DEVICE, JEOL JSM-5400LV SEM), SEM specimens were coated with gold to increase the conductivity. For the biological activity all microbial strains were kindly provided by the Assiut University Mycological Centre (AUMC), Egypt. These strains are common contaminants of the environment in Egypt and some of which are involved in human and animal diseases (Candida albicans, Geotrichum candidum, Scopulariopsis brevicaulis, Aspergillus flavus, Staphylococcus aureus), plant diseases (Fusarium oxysporum) or frequently reported from contaminated soil, water and food substances (Escherichia coli, Bacillus cereus, Pseudomonas aeruginosa and Serratia marcescens). To prepare inocula for bioassay, bacterial strains were individually cultured for $48 \mathrm{~h}$ in $100 \mathrm{ml}$ conical flasks containing $30 \mathrm{ml}$ nutrient broth medium. Fungi were grown for 7 days in $100 \mathrm{ml}$ conicals containing $30 \mathrm{ml}$ Sabouraud's dextrose broth. Bioassay was done in $10 \mathrm{~cm}$ sterile plastic Petri plates in which microbial suspension $(1 \mathrm{ml} /$ plate $)$ and $15 \mathrm{ml}$ appropriate agar medium $(15 \mathrm{ml} /$ plate) were poured. Nutrient agar and Sabouraud's dextrose agar were respectively used for bacteria and fungi. After solidification of the media, $5 \mathrm{~mm}$ diameter cavities were cut in the solidified agar (4 cavities/plate) using sterile cork borer. The chemical compounds dissolved in dimethyl sulfuxide (DMSO) at $2 \% \mathrm{w} / \mathrm{v}(=20 \mathrm{mg} / \mathrm{ml})$ were pipetted in the cavities $(20 \mu \mathrm{l} /$ cavity). Cultures were then incubated at $28^{\circ} \mathrm{C}$ for $48 \mathrm{~h}$ in case of bacteria and up to 7 days in case of fungi. Results were read as the diameter (in $\mathrm{mm}$ ) of inhibition zone around cavities [16].

\section{Synthesis of the coordination polymers}

$\left[\mathrm{Co}(\mathrm{POZT})(\mathrm{BIMZ}) \mathrm{Cl}\left(\mathrm{H}_{2} \mathrm{O}\right)_{2}\right]_{\mathrm{n}}(\mathbf{1})$ : A methanolic solution $(10 \mathrm{~mL})$ of POZT $(0.1 \mathrm{~g}, 0.5 \mathrm{mmol})$ was slowly added into a hot methanolic solution $(10 \mathrm{~mL})$ of $\mathrm{CoCl}_{2} .6 \mathrm{H}_{2} \mathrm{O}(0.132 \mathrm{~g}, 0.5 \mathrm{mmol})$ and to it a methanolic solution $(10 \mathrm{~mL})$ of benzimidazole $(0.066 \mathrm{~g}, 0.5 \mathrm{mmol})$ was added drop wise. The resultant mixture was stirred for $1 \mathrm{~h}$ and filtered. The dark blue precipitate was separated, washed with distilled water and $\mathrm{EtOH}$ and then dried over $\mathrm{CaCl}_{2}$ in a desiccator. Anal. Calc. for $\mathrm{CoC}_{14} \mathrm{H}_{13} \mathrm{~N}_{5} \mathrm{SO}_{3} \mathrm{Cl}$ : C, 39.49; H, 3.08; N, 16.45; S, 7.53. Found: C, 39.11; $\mathrm{H}, 4.76 ; \mathrm{N}, 15.91$; $\mathrm{S}, 6.22$. IR data: $\nu \mathrm{OH} 3196(\mathrm{~s}), v \mathrm{C}=\mathrm{N} 1608(\mathrm{~s}), v \mathrm{C}-\mathrm{N}$ 1460 (s), 906 (s), vM-O 552 (m), vM-N 424 (m) cm ${ }^{-1}$, m.p. $280^{\circ} \mathrm{C}$.

$\left\{\left[\mathrm{Ni}(\mathrm{POZT})(\mathrm{BIMZ}) \mathrm{Cl}\left(\mathrm{H}_{2} \mathrm{O}\right)_{2}\right] \cdot 3 \mathrm{H}_{2} \mathrm{O}\right\}_{n}$ (2): It was synthesized adopting the same procedure as in case of $\mathbf{1}$. The molar ratio was $1: 1: 1$, $\mathrm{NiCl}_{2} .6 \mathrm{H}_{2} \mathrm{O}(0.132 \mathrm{~g}, 0.5 \mathrm{mmol})$, POZT $(0.1 \mathrm{~g}, 0.5 \mathrm{mmol})$ and BIMZ $(0.066 \mathrm{~g}, 0.5 \mathrm{mmol})$. A Green compound was isolated. Anal. Calc. for $\mathrm{NiC}_{14} \mathrm{H}_{19} \mathrm{~N}_{5} \mathrm{SO}_{6} \mathrm{Cl}$ : C, 35.05; H, 4.00; N, 14.60; S, 6.68. Found: C, 33.47; $\mathrm{H}, 3.86 ; \mathrm{N}, 14.14 ; \mathrm{S}, 7.99$. IR data: $v \mathrm{OH} 3385$ (s), $3150(\mathrm{w}), v \mathrm{C}=\mathrm{N} 1606$ (s), vC-N 1485 (s), 964 (m), vM-O 560 (m), vM-N 432 (m) cm-1 m.p. $285^{\circ} \mathrm{C}$.

$\left\{\left[\mathrm{Cu}(\mathrm{POZT})(\mathrm{BIMZ}) \mathrm{Cl}\left(\mathrm{H}_{2} \mathrm{O}\right)_{2}\right] \cdot 3 \mathrm{H}_{2} \mathrm{O}\right\}_{n}$ (3): A similar synthetic method as that for $\mathbf{1}$ was used except that the reaction solvent was replaced by ethanol $(10 \mathrm{~mL})$. A brown compound was obtained. Anal. Calc. for $\mathrm{CuC}_{14} \mathrm{H}_{19} \mathrm{~N}_{5} \mathrm{SO}_{6} \mathrm{Cl}$ : C, 34.70; H, 3.96; N, 14.45; S, 6.62. Found:
C, 33.42; H, 4.37; N, 14.01; S, 7.98. IR data: $v O H 3495$ (s), 3192 (m), $v \mathrm{C}=\mathrm{N} 1612$ (s), vC-N 1466 (s), 906 (s) vM-O 572 (m), vM-N 440 (s) $\mathrm{cm}^{-1}$, m.p. $276^{\circ} \mathrm{C}$.

$\left\{\left[\mathrm{Cd}(\mathrm{POZT})(\mathrm{BIMZ}) \mathrm{Cl}\left(\mathrm{H}_{2} \mathrm{O}\right)_{2}\right] \cdot 3 \mathrm{H}_{2} \mathrm{O}\right\}_{\mathrm{n}}$ (4): The same synthetic procedure as that for 1 was adopted except that $\mathrm{CoCl}_{2} \cdot 6 \mathrm{H}_{2} \mathrm{O}(0.132 \mathrm{~g}$, $0.5 \mathrm{mmol}$ ) was replaced by $\mathrm{CdCl}_{2} .2 \mathrm{H}_{2} \mathrm{O}(0.127 \mathrm{~g}, 0.5 \mathrm{mmol})$ (Figure 2). A white product was isolated. Anal. Calc. for $\mathrm{CdC}_{14} \mathrm{H}_{19} \mathrm{~N}_{5} \mathrm{SO}_{6} \mathrm{Cl}$ : C, 31.52; H, 3.59; N, 13.13; S, 6.01. Found: C, 33.96; H, 4.25; N, 11.72; S, 7.22. IR data: $v \mathrm{OH} 3500$ (s), 3190 (m), vC=N 1620 (s), 1483 (s), 928 (m), vM-O 550 (m), vM-N 430 (m) cm ${ }^{-1}$, m.p. $298^{\circ} \mathrm{C}$.

$\left\{\left[\mathrm{UO}_{2}(\mathrm{POZT})(\mathrm{BIMZ})(\text { ace })\left(\mathrm{H}_{2} \mathrm{O}\right)\right]_{\mathrm{n}}\right.$ (5): A mixture of equimolar quantity $(0.5 \mathrm{mmol})$ of $\mathrm{UO}_{2}(\mathrm{ac})_{2} \cdot 2 \mathrm{H}_{2} \mathrm{O}(0.236 \mathrm{~g})$ and POZT $(0.1 \mathrm{~g})$ in a methanolic solution $(15 \mathrm{~mL})$ was mixed with a methanolic solution $(10 \mathrm{~mL})$ of BIMZ $(0.066 \mathrm{~g}, 0.5 \mathrm{mmol})$ and heated for $2 \mathrm{~h}$, then gradually cooled to room temperature (Figure 3). A yellow compound was isolated. Anal. Calc. for $\mathrm{UO}_{2} \mathrm{C}_{16} \mathrm{H}_{14} \mathrm{~N}_{5} \mathrm{SO}_{4}$ : C, 29.91; H, 2.20; N, 10.90; $\mathrm{S}$, 5.00. Found: C, 30.30; H, 3.71; N, 9.96; S, 6.78. IR data: $v O H 3200(\mathrm{~m})$ $v \mathrm{C}=\mathrm{N} 1618$ (s), vC-N 1410 (m), 924 (m), vM-O 520 (m), vM-N 430 (m) $\mathrm{cm}^{-1}$, m.p. $298^{\circ} \mathrm{C}$.

\section{Results}

The coordination polymers were prepared by the reaction of 5-(3-pyridyl)-1,3,4-oxadiazole-2-thiol (neutralized with $\mathrm{NaOH}$ ), metal chlorides or acetate, and benzimidazole (dissolved in $\mathrm{EtOH}$ or $\mathrm{MtOH}$ ). The prepared compounds were found to react in the molar ratio 1 : 1: 1 metal: POZT: BIMZ. The complexes are air stable, insoluble in

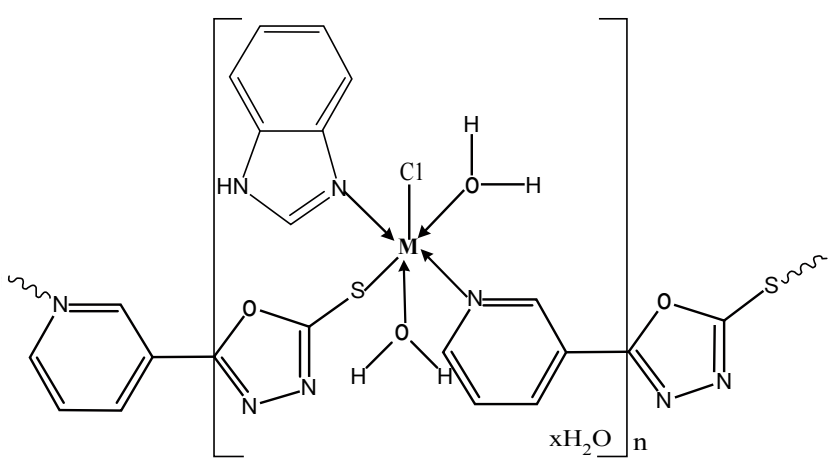

Figure 2: Suggested structure of $\left\{\mathrm{Cd}\left[\mathrm{M}(\mathrm{POZT})(\mathrm{BIMZ}) \mathrm{Cl}\left(\mathrm{H}_{2} \mathrm{O}\right)_{2}\right] \cdot \mathrm{xH}_{2} \mathrm{O}\right\}_{\mathrm{n}} \mathrm{M}=$ $\mathrm{Co}(\mathrm{II}), \mathrm{Ni}(\mathrm{II}), \mathrm{Cu}(\mathrm{II})$ and $\mathrm{Cd}(\mathrm{II}) \mathrm{x}=0$ or 3 .

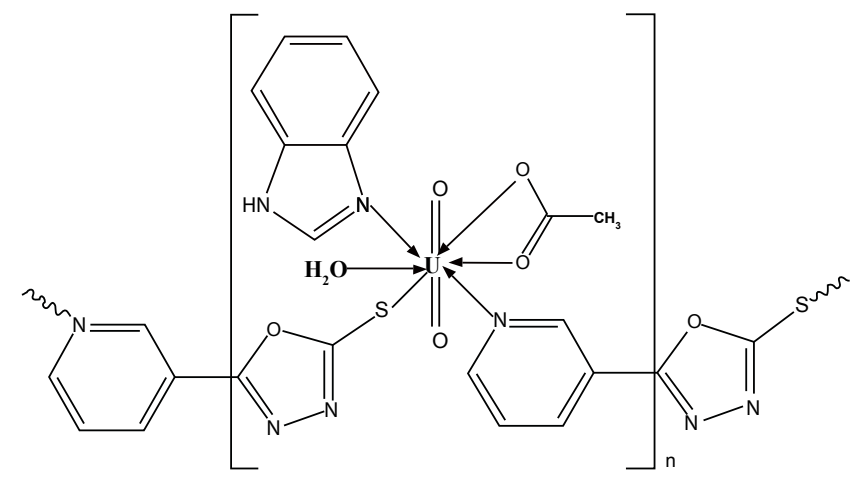

Figure 3: Suggested structure of $\left[\mathrm{UO}_{2}(\mathrm{POZT})(\mathrm{BIMZ})(\text { ace })\left(\mathrm{H}_{2} \mathrm{O}\right)\right]_{\mathrm{n}}$ 
Citation: Aly AAM, Ghandour MA, Abu-Zied BM, Al-Fakeh MS (2012) Synthesis, Properties and Environmentally Important Nanostructured and Antimicrobial Supramolecular Coordination Polymers Containing 5-(3-Pyridyl)-1,3,4-Oxadiazole-2-Thiol and Benzimidazole. J Environment Analytic Toxicol 2:129. doi:10.4172/2161-0525.1000129

Page 3 of 7

common organic solvents but partially soluble in DMSO. The electrical conductivity of the coordination polymers adequately supported their non-electrolytic nature.

\section{Fourier transform infrared spectroscopy (FT-IR)}

The main IR bands of each compound are cited in the experimental part. The bands observed in the $1606-1620 \mathrm{~cm}^{-1}$ regions are assigned to the $v(\mathrm{C}=\mathrm{N})$ stretching vibration of the POZT [17]. BIMZ exhibits two bands in the regions 906-964, 1414-1485 $\mathrm{cm}^{-1}$ which can be assigned to $v(\mathrm{C}-\mathrm{N})$ ring [12]. Furthermore, it is found that the bands at 3385$3500 \mathrm{~cm}^{-1}$ in the spectra of compounds 2,3 and 4 are assigned to $v \mathrm{OH}$ of water of crystallization [18] whereas the $\mathrm{vOH}$ stretching vibrations of the coordinated water molecules are located in the range 3150$3200 \mathrm{~cm}^{-1}$ for all compounds [19]. Metal-oxygen and metal-nitrogen bonding are manifested by the appearance of a band in the 520-572 $\mathrm{cm}^{-1}$ and $424-440 \mathrm{~cm}^{-1}$ region, respectively [20].

\section{Electronic Spectra}

The UV-Vis spectra of the coordination polymers in dimethylsulphoxide (DMSO) display two absorption maxima located in the regions 34,482-39,682 and 21,186-27,777 $\mathrm{cm}^{-1}$ which are attributed to $\pi \rightarrow \pi^{*}$ and $n \rightarrow \pi^{*}$ transitions within the POZT and BIMZ ligands $[12,16]$. The $\mathrm{Co}(\mathrm{II}), \mathrm{Ni}(\mathrm{II})$ and $\mathrm{Cu}(\mathrm{II})$ coordination polymers exhibit a band at $16,129,17,543$ and $15,337 \mathrm{~cm}^{-1}$ respectively corresponding to the $\mathrm{d}$ - $\mathrm{d}$ transitions. Additionally, the magnetic moments of the compounds were measured and it has been found that the cobalt(II) compound $\mathbf{1}$ has a magnetic moment of 4.43 B.M typical for the octahedral complexes [21] whereas the magnetic moment values 1.90, 2.10 B.M were found for the $\mathrm{Ni}(\mathrm{II}) 3$ and $\mathrm{Cu}(\mathrm{II}) 4$ compounds respectively suggesting their octahedral structures [22,23]. However, the low value of magnetic moment for the $\mathrm{Ni}$ (II) complex may be attributed to the presence of a mixture of square planar and octahedral geometries [24]. The electronic spectral data are shown in (Table 1). From the above data the structure of the coordination polymers can be postulated as follows:

\section{Thermal Studies}

The thermal decomposition of the coordination polymers has been investigated in dynamic air from ambient temperature to $750^{\circ} \mathrm{C}$ (Table 2). As a following example the thermogram of the cadmium(II) compound 4 shows four stages in the temperature ranges 53-92, 93$176,177-235$ and $236-750^{\circ} \mathrm{C}$ (Figure 4). The first and second stages correspond to the release of the two coordinated and the three craystalline water molecules (calc.16.89\%, found $15.32 \%$ ). The DTG curve shows these two steps at 63 and $131^{\circ} \mathrm{C}$ and two endothermic peaks at 66 and $133^{\circ} \mathrm{C}$ are recorded in the DTA trace. The third and forth steps represent decomposition of the organic ligands. These two steps are manifested by two DTG peaks at 200 and $525^{\circ} \mathrm{C}$ and are associated with two exothermic peaks at 201 and $527^{\circ} \mathrm{C}$ in the DTA curve. The final product was identified on the basis of mass loss considerations to be $\mathrm{CdO}$ (calc. $24.07 \%$, found $25.76 \%$ ). (Scheme 1 ).

Kinetic analysis: Non-isothermal kinetic analysis of the complexes was carried out applying two different procedures: the Coats-Redfern [24] and the Horowitz-Metzger [25] methods.

\section{(i) The Coats-Redfern equation}

$$
\begin{aligned}
& \ln [1-(1-\alpha) 1-n /(1-n) T 2]=M / T+B \text { for } \mathrm{n} \neq 1(1) \\
& \ln [-\ln (1-\alpha) / T 2]=M / T+B \text { for } \mathrm{n}=1 \text { (2) }
\end{aligned}
$$

\begin{tabular}{|c|c|c|c|}
\hline Compounds & $v \max \left(\mathrm{cm}^{-1}\right)$ & Assignment & $\mu$ eff B.M \\
\hline 1 & $\begin{array}{l}16,129 \\
25,125 \\
35,211\end{array}$ & $\begin{array}{l}d-d \text { transition } \\
n \rightarrow \pi^{*} \text { transition } \\
\pi \rightarrow \pi^{*} \text { transiton }\end{array}$ & 4.43 \\
\hline 2 & $\begin{array}{l}17,543 \\
27,777 \\
35,971 \\
\end{array}$ & $\begin{array}{l}d-d \text { transition } \\
n \rightarrow \pi^{*} \text { transition } \\
\pi \rightarrow \pi^{*} \text { transition }\end{array}$ & 2.10 \\
\hline 3 & $\begin{array}{l}15,337 \\
21,186 \\
34,482\end{array}$ & $\begin{array}{l}d-d \text { transition } \\
n \rightarrow \pi^{*} \text { transition } \\
\pi \rightarrow \pi^{*} \text { transition }\end{array}$ & 1.90 \\
\hline 4 & $\begin{array}{l}27,472 \\
39,682\end{array}$ & $\begin{array}{l}n \rightarrow \pi^{*} \text { transition } \\
\pi \rightarrow \pi^{*} \text { transition }\end{array}$ & - \\
\hline 5 & $\begin{array}{l}14,752 \\
27,322 \\
39,525\end{array}$ & $\begin{array}{l}\text { d-d transition } \\
n \rightarrow \pi^{*} \text { transition } \\
\pi \rightarrow \pi^{*} \text { transition }\end{array}$ & - \\
\hline
\end{tabular}

where $\alpha$ is the fraction of material decomposed, $\mathrm{n}$ is the order of
Table 1: Electronic spectral data and magnetic moments of the compounds.

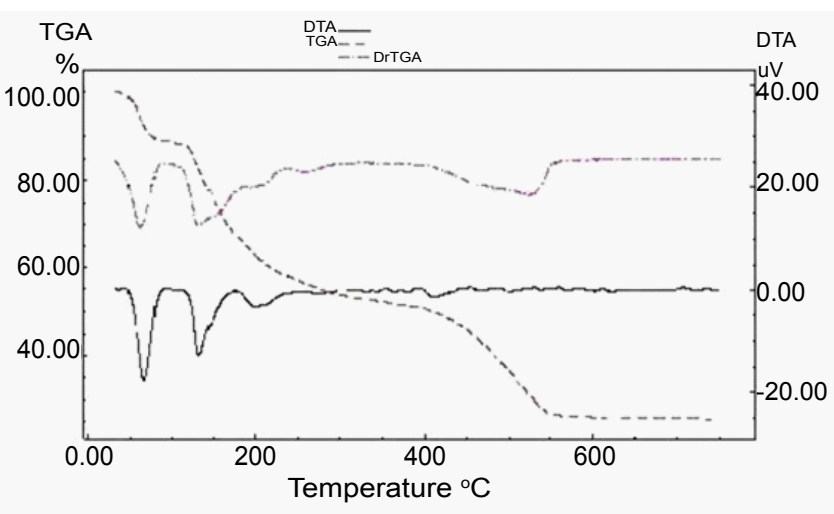

Figure 4: TG, DTG and DTA thermo grams of compound 4 in dynamic air.

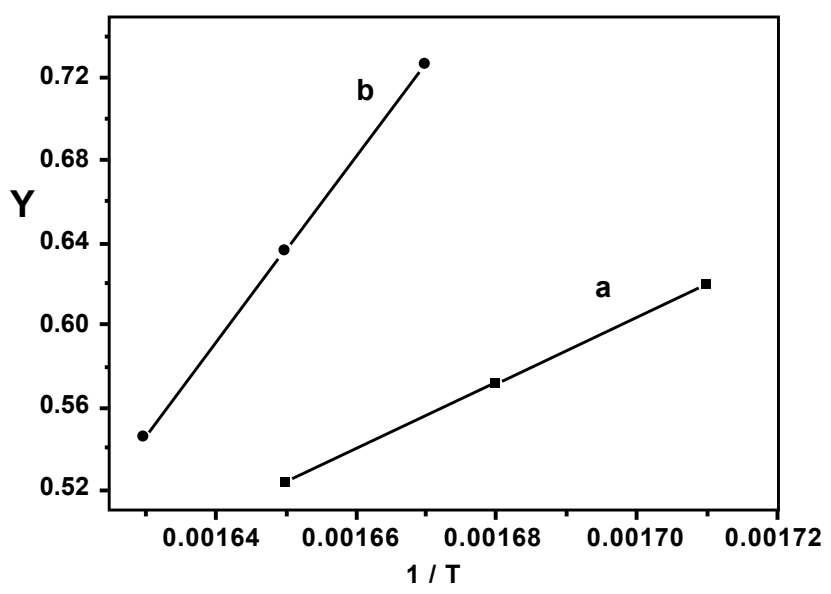

Figure 5: Coats-Redfern plots for a) compound 4 and b) compound 5 first step in dynamic air where $Y=\ln [1-(1-\alpha) 1-n /(1-\alpha)$ T2] for $n \neq 1$ or $Y=\ln [-\ln$ (1- $\alpha)$ / T2] for $n=1$.

the decomposition reaction and $\mathrm{M}=-\mathrm{E} / \mathrm{R}$ and $\mathrm{B}=\mathrm{ZR} / \Phi \mathrm{E} ; \mathrm{E}, \mathrm{R}, \mathrm{Z}$ and $\Phi$ are the activation energy, gas constant, pre-exponential factor and heating rate, respectively.

\section{(ii) The Horowitz-Metzger equation}

$\ln [1-(1-\alpha) 1-n / 1-n]=\operatorname{lnZRTs} 2 / \Phi E-E / R T s+E \theta / R T s 2$ for $n \neq 1(3)$

$\ln [-\ln (1-\alpha)]=\mathrm{E} \theta / \mathrm{RTs} 2$ for $\mathrm{n}=1(4)$ 
Citation: Aly AAM, Ghandour MA, Abu-Zied BM, Al-Fakeh MS (2012) Synthesis, Properties and Environmentally Important Nanostructured and Antimicrobial Supramolecular Coordination Polymers Containing 5-(3-Pyridyl)-1,3,4-Oxadiazole-2-Thiol and Benzimidazole. J Environment Analytic Toxicol 2:129. doi:10.4172/2161-0525.1000129

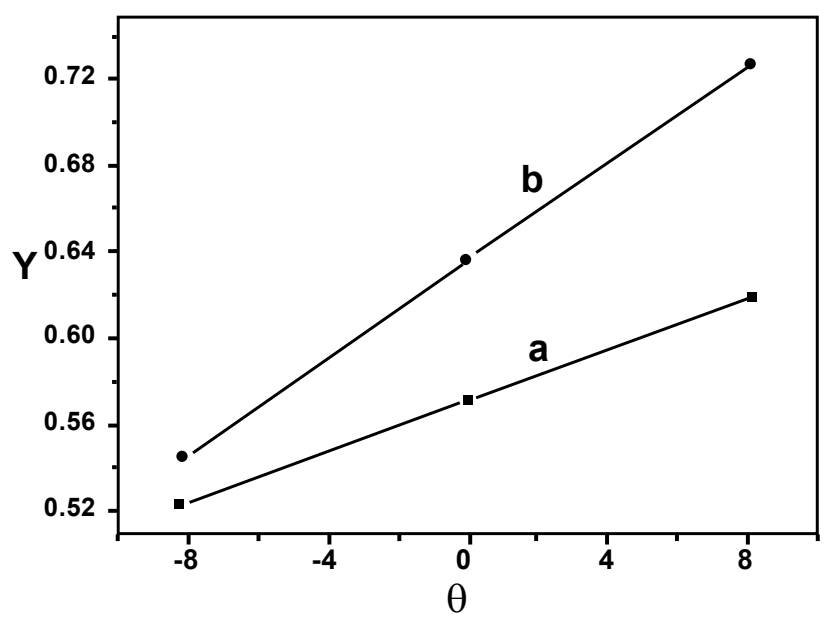

Figure 6: Horowitz-Metzger plots for a) compound 4 and b) compound 5 first step in dynamic air where $Y=\ln [1-(1-\alpha) 1-n /(1-n)]$ for $n \neq 1$ or $Y=\ln [-\ln$ $(1-\alpha)]$ for $n=1$.

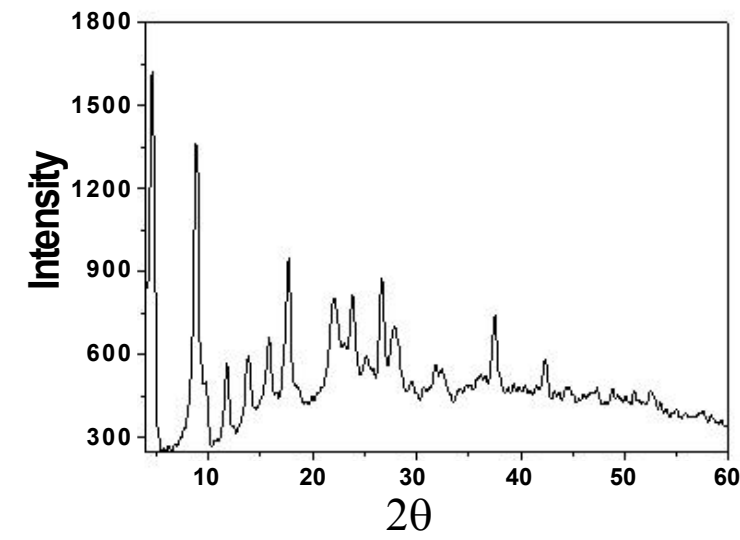

Figure 7: X-ray powder diffraction of $\left\{\left[\mathrm{Cu}(\mathrm{POZT})(\mathrm{BIMZ}) \mathrm{Cl}\left(\mathrm{H}_{2} \mathrm{O}\right)_{2}\right] \cdot 3 \mathrm{H}_{2} \mathrm{O}\right\}_{n}$

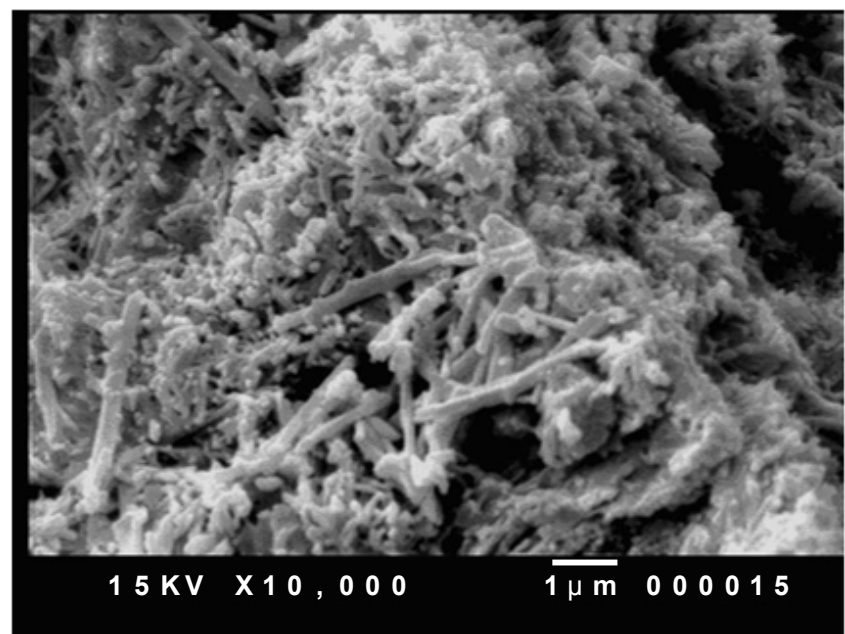

Figure 8: SEM of compound 3 where $\theta=\mathrm{T}$-Ts, Ts is the temperature at the DTG peak. The correlation coefficient $r$ is computed using the least squares method for equations (1), (2), (3) and (4). Linear curves were drawn for different values of $n$ ranging from 0 to 2 . The value of $n$, which gave the best fit, was chosen as the order parameter for the decomposition stage of interest. The kinetic parameters were calculated from the plots of the left hand side of equations (1),(2), against $1 / \mathrm{T}$ and against $\theta$ for equations (3) and (4) (Figure 5, 6). The kinetic parameters for compounds 1 , 4 and 5 were calculated for the first step according to the above two methods and are cited in Table 3, 4. The thermodynamic parameters $\Delta \mathrm{S}^{*}, \Delta \mathrm{H}^{*}$ and $\Delta \mathrm{G}^{*}$ for the three complexes 1,4 and 5 were computed using the following equations:

$$
\begin{aligned}
& \Delta \mathrm{S}^{*}=\mathrm{R}[\ln \mathrm{Zh} / \mathrm{kTs}](5) \\
& \Delta \mathrm{H}^{*}=\Delta \mathrm{E}^{*}-\mathrm{RTs}(6) \\
& \Delta \mathrm{G}^{*}=\Delta \mathrm{H}^{*}-\mathrm{Ts} \Delta \mathrm{S}^{*}(7)
\end{aligned}
$$

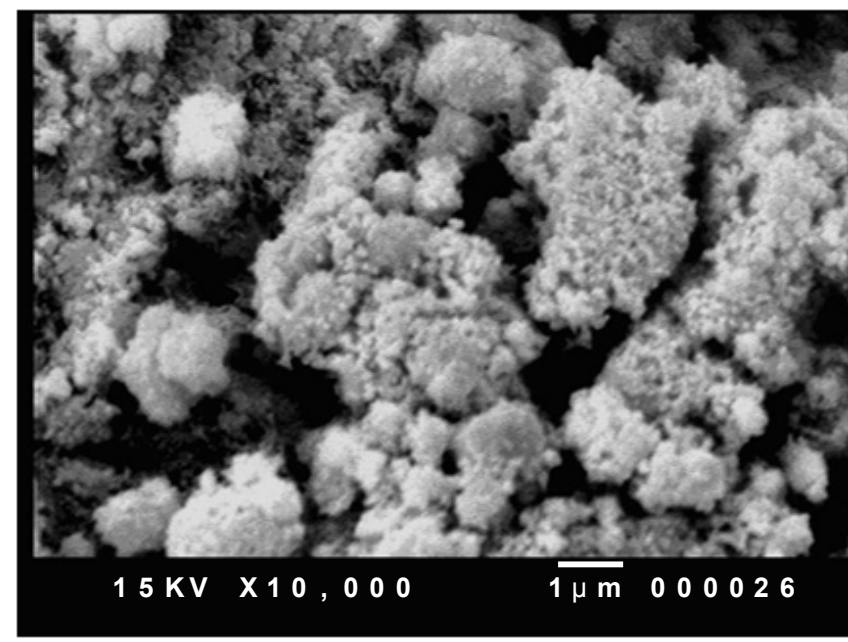

Figure 9: SEM of compound 4.

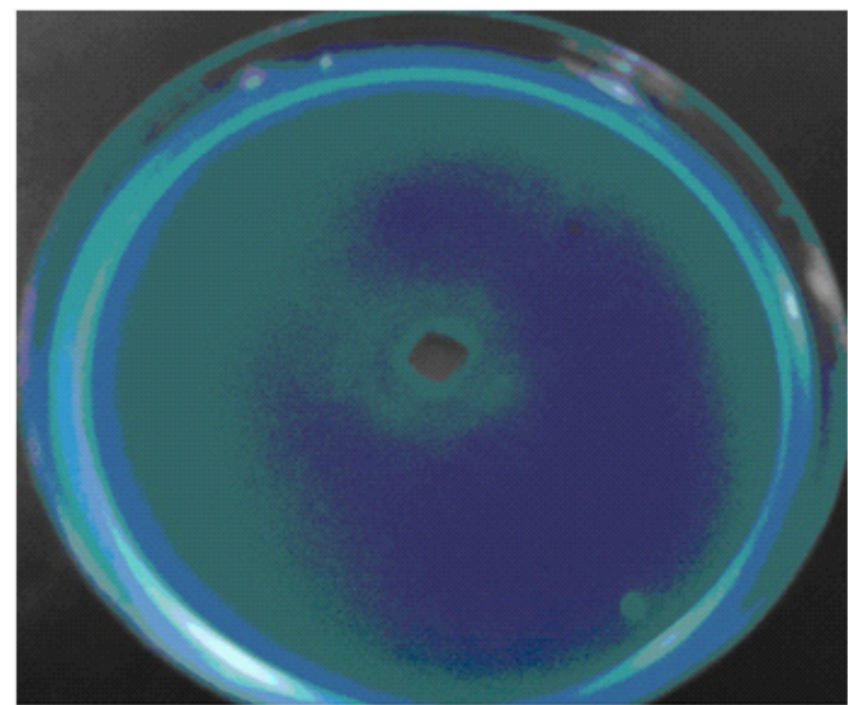

Figure 10: Microbiological screening of compound 1 against Pseudomonas aeruginosa(-ve) 
Citation: Aly AAM, Ghandour MA, Abu-Zied BM, Al-Fakeh MS (2012) Synthesis, Properties and Environmentally Important Nanostructured and Antimicrobial Supramolecular Coordination Polymers Containing 5-(3-Pyridyl)-1,3,4-Oxadiazole-2-Thiol and Benzimidazole. J Environment Analytic Toxicol 2:129. doi:10.4172/2161-0525.1000129

where h, Planck's constant, $\mathrm{k}$, Boltzmann constant, R, gas constant and Ts, temperature at the DTG peak. Negative $\Delta S^{*}$ value for the different stages of decomposition of the complexes suggest that the activated complex is more ordered than the reactants and that the reactions are slower than normal [26-28]. The more ordered nature may be due to the polarization of bonds in the activated state, which might happen through charge transfer electronic transition [29]. The different values of $\Delta \mathrm{H}^{*}$ and $\Delta \mathrm{G}^{*}$ of the complexes refer to the effect of the structure of the metal ions on the thermal stability of the complexes [30]. The positive values of $\Delta \mathrm{G}^{*}$ indicate that the decomposition reaction is not spontaneous.

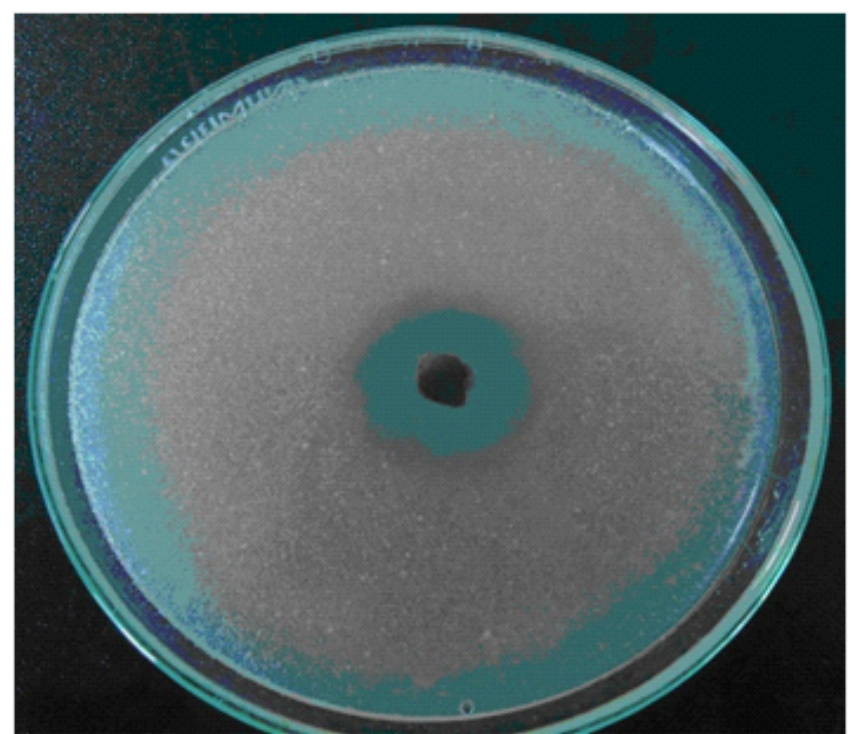

Figure 11: Microbiological screening of compound 4 against Candida albicans.

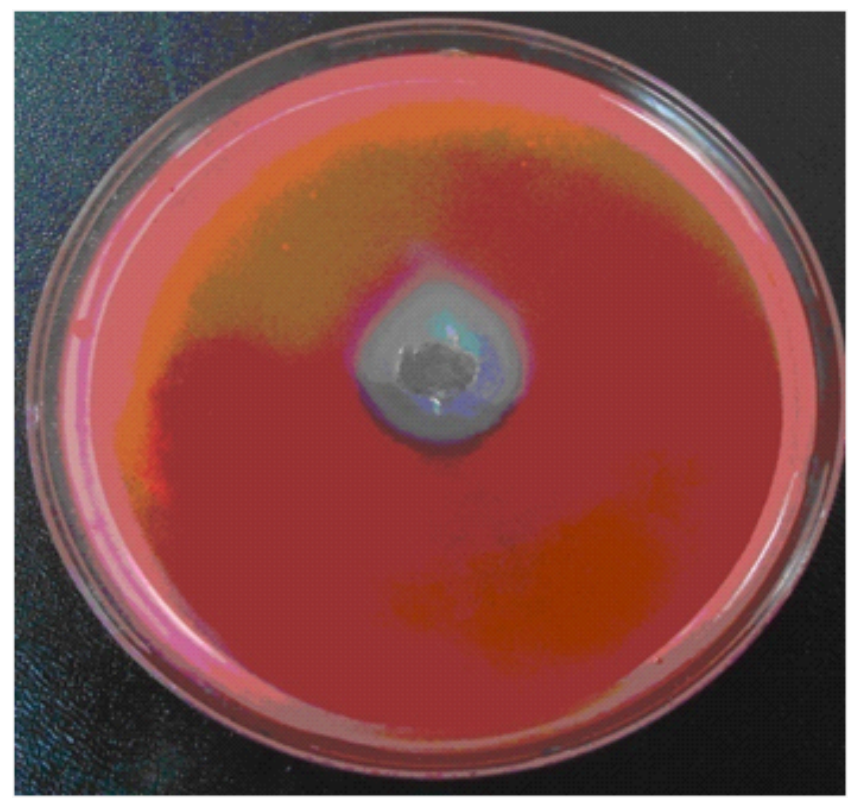

Figure 12: Microbiological screening of compound 5 against Serratia marcescens(-ve)

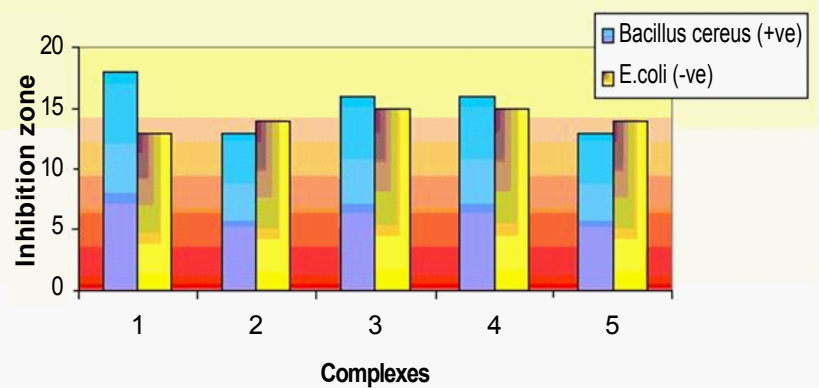

Figure 13: Comparison of coordination polymers of antibacterial activity.

\begin{tabular}{|l|c|c|c|c|c|}
\hline \multirow{2}{*}{ Compound } & \multirow{2}{*}{ Step } & \multicolumn{3}{|c|}{ TG/DTG } & Mass \\
\cline { 3 - 5 } & & Ti & Tm & Tf & Loss(\%) \\
\hline \multirow{3}{*}{1} & 1st & 50 & 68 & 156 & 5.37 \\
& 2nd & 157 & 217 & 244 & 2.93 \\
& 3rd & 245 & 325 & 371 & 19.69 \\
\hline \multirow{3}{*}{4} & 4th & 372 & 475 & 750 & 44.07 \\
\hline \multirow{3}{*}{5} & 1st & 53 & 64 & 92 & 11.01 \\
& 2nd & 93 & 131 & 176 & 4.31 \\
& 3rd & 177 & 201 & 235 & 26.30 \\
& 4th & 236 & 525 & 750 & 32.62 \\
\hline
\end{tabular}

$\mathrm{Ti}=$ Initial temperature, $\mathrm{Tm}=$ Maximum temperature, $\mathrm{Tf}=$ Final temperature.

Table 2: Thermal decomposition data of the compounds in dynamic air.

\section{$\mathrm{X}$-ray powder diffraction of the complexes}

The X-ray powder diffraction patterns were recorded for the coordination polymers 3 and $\mathbf{4}$. The diffraction patterns indicate that the compounds are crystalline. The crystal lattice parameters were computed with the aid of the computer program TREOR. The crystal data for $\mathbf{3}$ and $\mathbf{4}$ metal mixed-ligand compounds belong to the crystal system triclinic (Table 5). The significant broadening of the diffraction patterns suggests that the particles are of nanometer dimensions. XRD of compound 3 is depicted in Figure 7. Scherrer's equation (8) was applied to estimate the particle size of the coordination polymers:

$$
\mathrm{D}=\mathrm{K} \lambda / \beta \cos \theta(8)
$$

where $\mathrm{K}$ is the shape factor, $\lambda$ is the $\mathrm{X}$-ray wavelength typically 1.54 $\AA, \beta$ is the line broadening at half the maximum intensity in radians and $\theta$ is Bragg angle, $\mathrm{D}$ is the mean size of the ordered (crystalline) domains, which may be smaller or equal to the grain size. The crystal data together with the particle size are recorded in

Scanning electron micrographs (SEM): The scanning electron micrographs of copper (II) and cadmium (II) mixed ligand coordination polymers as representatives are given in Figure 8,9. The figures show the different morphologies of the compounds. The rod shape is apparent in the micrograph of compound 3.

\section{Biological activity}

In testing the antibacterial and antifungal activity of these compounds we used more than one test organism to increase the chance of detecting antibiotic principles in tested materials. The data showed that in some cases the ligand has a higher or similar antimicrobial and antifungal activity than the selected standards (chloramphenicol and clotrimazole). Also, the complexes of certain metal ions enhanced the 
Citation: Aly AAM, Ghandour MA, Abu-Zied BM, Al-Fakeh MS (2012) Synthesis, Properties and Environmentally Important Nanostructured and Antimicrobial Supramolecular Coordination Polymers Containing 5-(3-Pyridyl)-1,3,4-Oxadiazole-2-Thiol and Benzimidazole. J Environment Analytic Toxicol 2:129. doi:10.4172/2161-0525.1000129

Page 6 of 7

\begin{tabular}{|c|c|c|c|c|c|c|c|c|c|}
\hline \multirow{2}{*}{ Compound } & \multirow{2}{*}{ Step } & \multicolumn{4}{|c|}{ Coats-Redfern equation } & \multicolumn{4}{|c|}{ Horowitz-Metzger equation } \\
\hline & & $\mathbf{r}$ & $\mathbf{n}$ & $E$ & Z & $r$ & $\mathbf{n}$ & $E$ & $\mathbf{Z}$ \\
\hline 1 & $1^{\text {st }}$ & $\begin{array}{l}0.9919 \\
0.9907 \\
0.9912 \\
0.9901 \\
0.9895 \\
0.9967\end{array}$ & $\begin{array}{l}0.00 \\
0.33 \\
0.50 \\
0.66 \\
1.00 \\
2.00\end{array}$ & $\begin{array}{c}97.1 \\
106.2 \\
111.2 \\
116.0 \\
125.7 \\
159.7\end{array}$ & $\begin{array}{l}1.95 \times 10^{3} \\
2.13 \times 10^{3} \\
2.24 \times 10^{3} \\
2.34 \times 10^{3} \\
2.53 \times 10^{3} \\
3.24 \times 10^{3}\end{array}$ & $\begin{array}{l}0.9983 \\
0.9987 \\
0.9988 \\
0.9990 \\
0.9992 \\
0.9997\end{array}$ & $\begin{array}{l}0.00 \\
0.33 \\
0.50 \\
0.66 \\
1.00 \\
2.00\end{array}$ & $\begin{array}{l}105.1 \\
114.1 \\
118.6 \\
123.5 \\
133.4 \\
166.7\end{array}$ & $\begin{array}{l}5.19 \times 10^{4} \\
1.07 \times 10^{5} \\
1.57 \times 10^{5} \\
2.32 \times 10^{5} \\
5.11 \times 10^{5} \\
6.39 \times 10^{6}\end{array}$ \\
\hline 4 & $1^{\text {st }}$ & $\begin{array}{l}0.9968 \\
0.9954 \\
0.9952 \\
0.9958 \\
0.9974 \\
0.9920\end{array}$ & $\begin{array}{l}0.00 \\
0.33 \\
0.50 \\
0.66 \\
1.00 \\
2.00\end{array}$ & $\begin{array}{l}18.4 \\
23.3 \\
25.5 \\
28.2 \\
34.5 \\
55.1\end{array}$ & $\begin{array}{c}5.34 \times 10^{6} \\
4.71 \times 10^{2} \\
5.16 \times 10^{2} \\
5.70 \times 10^{2} \\
6.97 \times 10^{2} \\
11.07 \times 10^{2}\end{array}$ & $\begin{array}{l}0.9996 \\
0.9998 \\
0.9999 \\
0.9999 \\
1.0000 \\
1.0000\end{array}$ & $\begin{array}{l}0.00 \\
0.33 \\
0.50 \\
0.66 \\
1.00 \\
2.00\end{array}$ & $\begin{array}{l}29.6 \\
34.9 \\
37.8 \\
40.7 \\
47.1 \\
69.8\end{array}$ & $\begin{array}{c}1.57 \times 10^{5} \\
2.42 \times 10^{5} \\
7.07 \times 10^{5} \\
8.05 \times 10^{5} \\
2.25 \times 10^{6} \\
11.53 \times 10^{6}\end{array}$ \\
\hline 5 & $1^{\text {st }}$ & $\begin{array}{l}0.9972 \\
0.9984 \\
0.9991 \\
0.9994 \\
0.9999 \\
0.9997\end{array}$ & $\begin{array}{l}0.00 \\
0.33 \\
0.50 \\
0.66 \\
1.00 \\
2.00\end{array}$ & $\begin{array}{c}51.35 \\
63.23 \\
70.84 \\
77.97 \\
95.00 \\
156.90\end{array}$ & $\begin{array}{l}1.03 \times 10^{3} \\
1.27 \times 10^{3} \\
1.42 \times 10^{3} \\
1.56 \times 10^{3} \\
1.80 \times 10^{3} \\
3.09 \times 10^{3}\end{array}$ & $\begin{array}{l}0.9992 \\
0.9996 \\
0.9998 \\
0.9824 \\
0.9998 \\
0.9995\end{array}$ & $\begin{array}{l}0.00 \\
0.33 \\
0.50 \\
0.66 \\
1.00 \\
2.00\end{array}$ & $\begin{array}{c}53.06 \\
64.15 \\
70.75 \\
89.34 \\
94.13 \\
147.50\end{array}$ & $\begin{array}{l}3.32 \times 10^{6} \\
6.65 \times 10^{6} \\
7.04 \times 10^{5} \\
5.87 \times 10^{6} \\
8.83 \times 10^{6} \\
3.78 \times 10^{4}\end{array}$ \\
\hline
\end{tabular}

$\mathrm{E}$ in $\mathrm{kJ} \mathrm{mol}^{-1}$, underlined $r$ in all tables represents the best fit values of $\mathrm{n}$ and $\mathrm{E}$

Table 3: Kinetic parameters for the thermal decomposition of the compounds.

\begin{tabular}{|c|c|c|c|c|}
\hline Compound & Step & $\Delta \mathbf{S}^{*}$ & $\Delta \mathbf{H}^{*}$ & $\Delta \mathbf{G}^{*}$ \\
\hline 1 & $1^{\text {st }}$ & -189.44 & 90.97 & 139.68 \\
\hline 4 & $1^{\text {st }}$ & -199.43 & 18.36 & 118.24 \\
\hline 5 & $1^{\text {st }}$ & -193.06 & 46.34 & 116.24 \\
\hline
\end{tabular}

$\Delta \mathrm{H}^{*}, \Delta \mathrm{G}^{*}$ are in $\mathrm{kJ}$ mol-1 and $\Delta \mathrm{S}^{*}$ in $\mathrm{kJ}$ mol-1 $\mathrm{K}-1$

Table 4: Thermodynamic parameters for the thermal decomposition of the compounds.

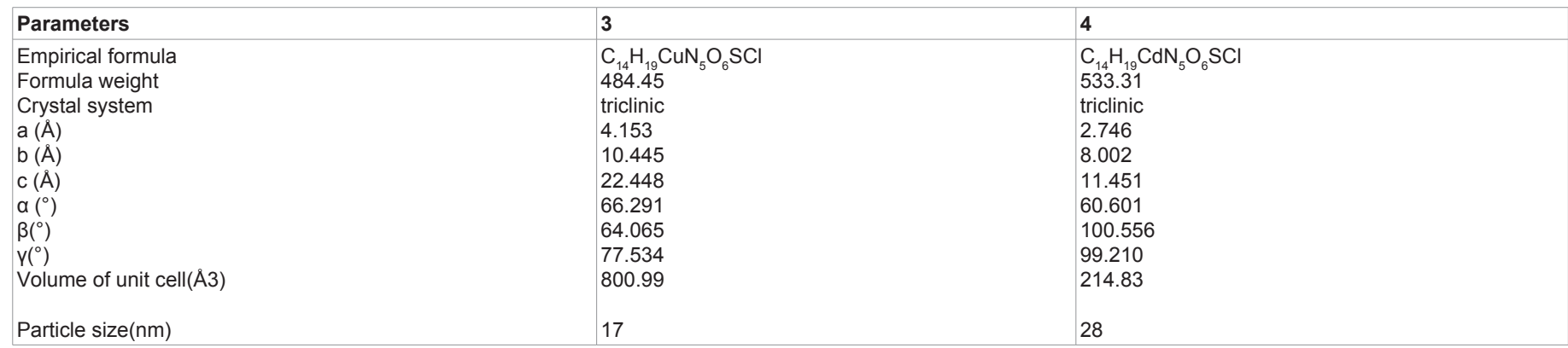

Table 5: X-ray diffraction crystal data of the compounds and their particle size.

\begin{tabular}{|c|c|c|c|c|c|c|c|c|c|c|c|}
\hline Compound & $\begin{array}{c}\text { B. } \\
\text { cereus } \\
\text { (G+ve) }\end{array}$ & $\begin{array}{c}\text { S. } \\
\text { aureus } \\
\text { (G+ve) }\end{array}$ & $\begin{array}{c}\text { S. } \\
\text { Marcescens } \\
(\text { G-ve })\end{array}$ & $\begin{array}{c}\text { E. } \\
\text { coli } \\
\text { (G-ve) }\end{array}$ & $\begin{array}{c}P . \\
\text { aeruginosa } \\
(\mathrm{G}-\mathrm{ve})\end{array}$ & $\begin{array}{c}\text { A. } \\
\text { flavus }\end{array}$ & $\begin{array}{c}\text { C. } \\
\text { albicans }\end{array}$ & $\begin{array}{c}\text { F. } \\
\text { oxysporm }\end{array}$ & $\begin{array}{c}\mathrm{T} . \\
\text { rubrum }\end{array}$ & $\begin{array}{c}\text { G. } \\
\text { candidum }\end{array}$ & $\begin{array}{c}\text { S. } \\
\text { brevicaulis }\end{array}$ \\
\hline 1 & 18 & 14 & 12 & 13 & 14 & 0 & 0 & 0 & 20 & 17 & 0 \\
\hline 2 & 13 & 15 & 14 & 14 & 12 & 0 & 0 & 12 & 13 & 16 & 0 \\
\hline 3 & 16 & 16 & 14 & 15 & 12 & 0 & 12 & 12 & 0 & 18 & 8 \\
\hline 4 & 16 & 13 & 12 & 15 & 13 & 28 & 15 & 12 & 28 & 14 & 16 \\
\hline 5 & 13 & 14 & 16 & 14 & 12 & 22 & 0 & 12 & 13 & 14 & 15 \\
\hline
\end{tabular}

Table 6: Microbiological screening of the compounds.

antimicrobial activity and in some case a higher or similar activity than the selected standards were shown Table 6. Figure 10-13 show the antimicrobial effect for these compounds.

\section{Acknowledgement}

One of the authors (A. A. M. ALY) is very grateful to Alexander Von Humboldt Foundation for donating the magnetic susceptibility balance (MSB-Auto ).

\section{References}

1. Brammer $L$ (2004) Developments in inorganic crystal engineering. Chem Soc Rev 33: 476-489.
2. Batten SR, Murray KS (2003) Coordination polymers: design, analysis and application. Coord. Chem Rev 246: 103.

3. Yaghi OM, Keeffe MO, Ockwig NW, Chae HK (2003) Reticular synthesis and the design of new materials. Nature 423: 705-714.

4. Zou RQ, Sakurai H, Xu Q (2006) Preparation, Adsorption Properties, and Catalytic Activity of 3D Porous Metal-Organic Frameworks Composed of Cubic Building Blocks and Alkali-Metal lons. Angew Chem Int Ed 45: 2542-2546.

5. Carlucci L, Ciani G, Proserpio DM (2003) Polycatenation, polythreading and polyknotting in coordination network chemistry. Coord Chem Rev 246: $247-$ 289. 
Citation: Aly AAM, Ghandour MA, Abu-Zied BM, Al-Fakeh MS (2012) Synthesis, Properties and Environmentally Important Nanostructured and Antimicrobial Supramolecular Coordination Polymers Containing 5-(3-Pyridyl)-1,3,4-Oxadiazole-2-Thiol and Benzimidazole. J Environment Analytic Toxicol 2:129. doi:10.4172/2161-0525.1000129

Page 7 of 7

6. Zhang ZH, Tian YL, Guo YM (2007) Porous Co(II) and Ni(II) coordination polymers based on 5-(4-pyridyl)-1,3,4-oxadiazole-2-thiol for various solvent inclusion. Inorganica Chim Acta 360: 2783-2788

7. Oae S (1992) Organic Sulfur Chemistry: Structure and Mechanism. CRC Press Boca Raton FL.

8. Singh NK, Bharty MK, Butcher RJ (2009) Synthesis and X-ray crystallographic studies of $\mathrm{Ni}$ (II) and $\mathrm{Cu}$ (II) complexes of [5-(4-pyridyl)-1,3,4] oxadiazole-2thione/thiol formed by transformation of $\mathrm{N}$-(pyridine-4-carbonyl)-hydrazine carbodithioate in the presence of ethylenediamine. Polyhedron 28: 2443-2449.

9. Zhang ZH, Li CP, Tang GM, Tian YL, Guo YM (2008) \{[Cd2(pyt)2(chdc) $(\mathrm{H} 2 \mathrm{O})](\mathrm{H} 2 \mathrm{O}) 2\} \mathrm{n}$ : A unique bilayer coordination polymer with mixed-connected network topology $(\mathrm{Hpyt}=5$-(4-pyridyl)-1,3,4-oxadiazole-2-thiol and $\mathrm{H} 2 \mathrm{chdc}=$ 1,4-cyclohexanedicarboxylic acid). Inorg Chem Commun 11: 326-329.

10. Wang YT, Tang GM (2007) One new nickel coordination polymer with an unsymmetric 5-(4-pyridyl)-1,3,4-oxadiazole-2-thione: Synthesis, structure and characterization. Inorg Chem Commun 10: 53-56.

11. Wang YT, Tang GM, Qiang ZW (2007) Radius-dependent assembly of complexes with the rigid unsymmetric ligand 5-(2-pyridyl)-1,3,4-oxadiazole-2thione: Syntheses, structures and luminescence properties. Polyhedron 26 : $4542-4550$.

12. Banu KS, Mondal S, Guha A, Das S (2011) Synthesis, characterization and luminescence properties of polymeric cadmium(II) complexes with imidazole and its derivatives mediated by thiocyanate and dicyanamide anions. Polyhedron 30: 163-168.

13a) Podunavac SO, Cvetkovic DM (2007) Antibacterial evaluation of some benzimidazole derivatives and their zinc(II) complexes. J Serb Chem Soc 72 : 459-466.

13b) Borisenko VE, Koll A, Kolmakov EE, Rjasnyi AG (2006) J Mol Struct 783 101-115.

14. Serezhkin VN (2007) Structural Chemistry of Inorganic Actinide Compounds. Elsevier

15. Lermontov AS, Lermontova EK, Wang YY (2009) Synthesis, structure and optic properties of 2-methylimidazolium and 2-phenylimidazolium uranyl acetates. Inorganica Chim Acta 362: 3751-3755
16. Kwon-Chung KJ, Bennett JE (1992) Medical mycology, Lea \& Febiger Philadelphia.

17. Singh M, Butcher RJ, Singh NK (2008) Syntheses and x-ray structural studies of the novel complexes [Ni(en)2(3-pyt)2] and [Cu(en)2](3-pyt)2 based on 5-(3-pyridyl)-1,3,4-oxadiazole-2- thione. Polyhedron 27: 3151-3159.

18. Wang YT, Tang GM, Ma WY, Wan WZ (2007) Synthesis and characterization of two new coordination supramolecular structures from a versatile unsymmetric 5-(4-pyridyl)-1,3,4-oxadiazole-2-thione (Hpot) ligand. Polyhedron 26: 782-790.

19. Bravo A, Anacona J (2001) Metal complexes of the flavonoid quercetin: antibacterial properties. Transition Met Chem 26: 20-23.

20. Rakha T (2000) Transition metal chelates derived from potassium nicotinoyldithiocarbazate (KHNDC). Synthesis and Reactivity in Inorganic and Metal-Organic Chemistry 30: 205-224

21. Lever $A B P(1986)$ Inorganic Electronic Spectroscopy. (2nd Ed) Elsevier Amsterdam

22. El-Asmy AA, Mounir M (1988) Electrical conductivity, spectral and magnetic properties of some transition metal complexes derived from dimedone bis(4phenylthiosemicarbazone). Transition Metal Chemistry 13:143-146.

23. Anacona JR, Toledo C (2001) Synthesis and antibacterial activity of metal complexes of ciprofloxacin. Transition Metal Chemistry 26: 228-231.

24. Coats A, Redfern J (1964) Nature 20:68

25. Horowitz H, Metzger G (1963) Anal Chem 35:1464

26. Mohamed GG, Hosny WM, Abd El-Rahim MA (2000) New binary and ternary complexes of fluclaxocillin and amino acids with some transition metal. Synthesis and Reactivity in Inorganic and Metal-Organic Chemistry 32: 1501 1519.

27. Beg MA, Qaiser MA (1998) Thermal behaviour of bis(diphenyltrifluoromethylphosphine)dichloroplatinum(II). Thermochimica Acta 210: 123-132.

28. Pandey OP, Sengupta SK, Tripathi SC (1985) Thermochemistry of metal xanthato complexes. A review Thermochimica Acta 96: 155-167.

29. Yusuff KM, Karthikeyan AR (1992) Thermal decomposition kinetics of mixed ligand complexes of cobaloxime with 1-benzyl-2-phenylbenzimidazole. Thermochimica Acta 207: 193-199.

30. Emam ME, Kanawy M, Hafe MH (2001) Study of the thermal decomposition of some new cyanine dispersed dyes. Journal of Thermal Analysis and Calorimetry 63: 75-83. 